\title{
The Moderator Role of Financial Well-Being on the Effect of Job Insecurity and the COVID-19 Anxiety on Burnout: A Research on Hotel-Sector Employees in Crisis
}

\author{
Engin Üngüren ${ }^{1}$, Ömer Akgün Tekin ${ }^{2, *}$, Hüseyin Avsall ${ }_{1}^{1, *}$ and Yaşar Yiğit Kaçmaz ${ }^{3}$ \\ 1 Department of Business Administration, Faculty of Economics and Administrative Sciences, \\ Alanya Alaaddin Keykubat University, Alanya 07450, Turkey; engin.unguren@alanya.edu.tr \\ 2 Department of Gastronomy and Culinary Arts, Manavgat Tourism Faculty, Akdeniz University, \\ Manavgat 07600, Turkey \\ 3 Alanya Alaaddin Keykubat University, Alanya 07450, Turkey; yykacmaz@hotmail.com \\ * Correspondence: omeratekin@akdeniz.edu.tr (Ö.A.T.); huseyin.avsalli@alanya.edu.tr (H.A.)
}

Citation: Üngüren, E.; Tekin, Ö.A.; Avsallı, H.; Kaçmaz, Y.Y. The Moderator Role of Financial Well-Being on the Effect of Job Insecurity and the COVID-19 Anxiety on Burnout: A Research on Hotel-Sector Employees in Crisis. Sustainability 2021, 13, 9031. https:// doi.org/10.3390/su13169031

Academic Editors:

Emanuele Cannizzaro and António Abreu

Received: 18 July 2021

Accepted: 6 August 2021

Published: 12 August 2021

Publisher's Note: MDPI stays neutral with regard to jurisdictional claims in published maps and institutional affiliations.

Copyright: (c) 2021 by the authors. Licensee MDPI, Basel, Switzerland. This article is an open access article distributed under the terms and conditions of the Creative Commons Attribution (CC BY) license (https:/ / creativecommons.org/licenses/by/ $4.0 /)$.

\begin{abstract}
During the coronavirus disease 2019 (COVID-19) pandemic, which is caused by the severe acute respiratory syndrome coronavirus 2 (SARS-CoV-2), hotel-sector employees attempted to cope with the fear of becoming infected; however, they were also faced with job insecurity. Both the anxiety over COVID-19 and the risk of job insecurity have affected the employees' economic and social conditions as well as their mental state. The present study examined the effect of COVID-19 anxiety and job insecurity perceptions on the burnout levels of hotel-sector employees and the moderator role of the employees' financial well-being on this relationship. The study was conducted by collecting data from 396 participants who worked in 17 different five-star hotels in Antalya, Turkey. Because of social isolation and social distancing rules, our research data were obtained using an online questionnaire to avoid close contact with other people. The findings showed that COVID-19 anxiety and perceptions of job insecurity had negative effects on hotel employees in the form of mental burnout. In addition, we determined that as an individual characteristic, financial well-being was a moderator variable that affected the severity of burnout based on COVID-19 anxiety and job insecurity. The research findings exhibited theoretical and practical contributions for decision makers and researchers.
\end{abstract}

Keywords: COVID-19 anxiety; job insecurity; burnout syndrome; financial well-being; hospitality employees

\section{Introduction}

The tourism and hotel industry is one of the primary defenseless sectors against external shock, such as epidemic diseases and natural disasters [1,2]. For example, in 2003, after the severe acute respiratory syndrome (SARS) outbreak, the tourism industry lost more than 3 million jobs, which caused an economic loss of $>\$ 20$ billion in East Asia [3-5]. During this outbreak, 75\% of employees in the leisure and hospitality industries lost their jobs in Toronto, Canada [6], and in Hong Kong, China, the influx of tourist declined by 80\%, which caused a dramatic unemployment crisis for the hotels, recreational and amusement parks, and catering services [7]. After the Hurricane Katrina devastation in New Orleans, Louisiana, 1409 hotels shut down, and 33,000 hotel employees lost their jobs [8]. SARS coronavirus 2 (SARS-CoV-2), which causes coronavirus disease 2019 (COVID-19), was an epidemic that first broke out in Wuhan, China, in December 2019 and spread throughout the world within a very short period of time [9]. This "pandemic" devastated the tourism and hotel industries more than any other disasters and epidemics and brought hotel operations nearly to a standstill in most countries [10]. These results very clearly and tragically illustrated how defenseless the tourism sector is against epidemic diseases and disasters. 
COVID-19 is an extremely infectious disease that is transmitted through droplets expelled from the nose and mouth of an infected person who sneezes or coughs [9]. By nature, the employees within the tourism and hotel industries, who are the first to be contacted by the tourists, must have personal contact with customers from various countries [11]. Because these employees work in a high-contact environment, they are at high risk for COVID-19 infection [12]. In one sector, an increase in the risk of catching a contagious disease resulting from the working conditions weighs heavily on the mental health of the employees [13]; therefore, the high risk for hotel employees of becoming infected may be psychologically destructive for them [11,14]. Because of the COVID-19 pandemic, foreign flights were suspended; intercity travel was restricted; hotels, restaurants, bars, holiday villages, and amusement parks were closed; and collective events, such as concerts and outdoor food gatherings, were cancelled in many countries [1]. The quarantine measures caused job losses and financial uncertainties, particularly for those who lived in developing countries [15]. Although the tourism-sector employees who struggled under these conditions attempted to prevent being exposed to the pandemic, they lost their jobs and incomes. Research conducted on this subject has indicated that people began to panic from the threat of losing their jobs and incomes [16]. The results of the study by Zhang et al. [17] have indicated that those who had to quit their jobs in China because of the COVID-19 pandemic experienced both mental and physical health problems; consequently, the COVID-19 pandemic has threatened both and has negatively affected employment sustainability. This indicates that COVID-19 is not only a physical health risk but is also a heavy burden on an individual's mental health [18].

Empirical research is necessary that would study how health crises and disasters affect hotel employees' attitudes and behaviors [19]. In addition, it is important to understand the individual effects of epidemics like COVID-19 that significantly affect an entire society [20]. The present study aimed to contribute to the literature by examining the effects of the COVID-19 process on the psychological status of hotel employees. The variables used in this study were approached based on the job demands-resources (JD-R) model and the conservation of resources (COR) theory. Because hotel employees work in a high-contact environment, they have a greater risk of becoming infected [21] with any contagious disease from patrons, and the COVID-19 pandemic increased the risk of job insecurity for these employees, which may have negatively affected their mental health according to the JD-R model and COR theory [12]. According to the COR theory, to maintain their psychological health, individuals attempt to protect the resources they own or reduce the consumption of resources [22]. Job security is one of the main expectations of employees within the tourist industry. While being unable to provide job security because of uncertainties during the pandemic, financial insecurity was also an issue according to the JD-R model theory [23], which may cause mental and psychological resources to be exhausted. The JD-R model is considered to be a functional model used to evaluate an employee's well-being [24]. In this regard, the current study had two main objectives. The first was to determine the effect of the COVID-19 pandemic-related anxiety and the fear of job insecurity on the burnout levels of hotel-industry employees. Financial insecurity and burnout attract a great deal of attention from researchers and decision makers because of their potential effects on the employees' welfare and effectiveness [25]. According to the COR theory, financial well-being has a protective function against the negative effects caused by stress. Although emotional burnout has been widely examined in the travel and hotel industries, individual differences in the experience of emotional burnout have not been widely addressed [26]. In addition, the results of previous research have maintained that although people have a certain level of anxiety about COVID-19, the reactions of the pandemic show great differences among individuals [27]; therefore, examining the effect of an individual's anxiety regarding the COVID-19 pandemic and the effects of his or her perceived job insecurity from the pandemic on burnout based on individual characteristics is important to be able to better understand the conditions under which the individuals are able to cope with the pandemic. The second main objective in the present study was to determine how 
financial well-being moderated the effects on burnout from anxiety about COVID-19 and the fear of job insecurity. The COVID-19 pandemic continues despite studies on vaccination results, and the hotel sector is included among those most affected by this pandemic, which helps decision makers and policy makers protect the mental health of hotel employees. The findings from the present study contribute to understanding the effects of financial well-being among the individual factors on burnout against the situations that threaten both employee health and job security during such difficult times.

\section{Theoretical Background and Hypotheses Development}

\subsection{Relationship between COVID-19 Anxiety and Burnout Syndrome}

Together with the emergence of the COVID-19 pandemic, a huge socioeconomic crisis and a negative psychological climate have spread worldwide [28]. People have the tendency to live in clinically significant fear and anxiety under pandemic conditions [29] because unfavorable information that spreads from the media concerning the pandemic affects an individual's psychology in a negative way [30]. Several recent studies conducted using participants from various countries [31-37] have determined that individuals experience psychological problems, such as anxiety, fear, stress, insomnia, panic attack, depression, and suicidal tendencies, resulting from COVID-19. Anxiety, which is perceived as a threat for the future and defined as a feeling of tension and worry [38], plays a significant role in these psychological problems [39]. Anxiety is a health-, family-, and economy-related problem in general [40], and the existing pandemic conditions threaten all of these. This threat perception was extremely high in tourism-sector employees during the pandemic because they must accommodate customers on a one-to-one basis [41]. Anxiety is not only a psychological problem; it is a factor that affects burnout syndrome. In several studies, there are various findings regarding the significant relationship between the subdimension of emotional burnout and anxiety [42], work-related anxiety [43,44], and economic anxiety that increases the burnout levels of employees [40], and the increase in this burnout level causes an increase in anxiety [45]. In addition, in a research conducted in the United Kingdom, it was determined that $51 \%$ of the participants simultaneously experienced both anxiety and burnout [46].

On the other hand, fear and anxiety are closely related concepts [47]. Several studies have been conducted on the relationships between COVID-19 fear and burnout. Chen and Eyoun [48] have determined that COVID-19 fear increases burnout. Yakut et al. [49] and Y1ldirım and Solmaz [50] have indicated that the stress factor caused by COVID-19 fear creates a proper environment for burnout. Bakioğlu et al. [51] have found that COVID-19 fear has significant and positive effects on anxiety. In their study, Satici et al. [52] have determined that, in addition to causing anxiety, COVID-19 fear negatively affects depression and stress. Findings obtained from the literature point out that COVID-19-based fear and anxiety negatively affect burnout levels. In accordance with this, it was considered that any increases in COVID-19-oriented anxiety levels within tourism-sector employees increases their burnout levels, and the following H1 hypothesis was constructed.

Hypothesis 1 (H1). COVID-19 anxiety is positively correlated (negatively affect) with the burnout levels of hotel employees.

\subsection{Relationship between Job Insecurity and Burnout Syndrome}

It can be stated that the academic interest in job insecurity research began with the seminal article by Greenhalgh and Rosenblatt [53] in which they discussed the issue [54]. Greenhalgh and Rosenblatt [53] have defined the concept of job insecurity as "perceived powerlessness to maintain desired continuity in a threatened job situation", and Sverke et al. [55] have explained this concept as the subjectively perceived and undesired possibility of losing the present job. The perception of job insecurity causes the emergence of destructive reactions in individuals [56] and results in remarkable negative organizational and individual outcomes. The perception of job insecurity has negative effects in 
terms of organizational perspective in variables, such as organizational commitment [57], workplace health and safety [58], impaired family well-being [59], job satisfaction [60], job engagement [1], and work performance [19]. Examining the individual outcomes of the job insecurity perception, it has been suggested that this problem primarily negatively affects general health [61,62], may trigger coronary heart diseases [63], and harms the physical and physiological health [64] and well-being of the employees [65]. Several studies have asserted that there are also positively directed relationships between an individual's perception of job insecurity and their burnout levels [66]. Job insecurity is an important stressor [67], and burnout that emerges as a result of job insecurity is a chronic stress reaction that develops to cope with various stress sources [68]; therefore, it is considered that stress that emerges with an employee's perception of job insecurity also negatively affects his or her burnout level.

In the study conducted on municipal police, Çetin [69] had determined that there are positively significant relationships between job insecurity perceptions and burnout levels in these individuals. In the study conducted on nurses who work in a state university hospital, Bitmiş and Ergeneli [70] have concluded that an increase in their job insecurity perception also significantly increases their burnout levels. In the study conducted by Oprea and Iliescu [71] on the employees of the IT department in a multinational company, it was found that as the employee's perception of job insecurity increases, his or her burnout level increases. A research conducted by Douglas et al. [72] with the employees from various sectors in Australia found that job insecurity increases burnout; however, the variable of union membership has a diminishing effect on burnout levels. In the context of the two-step research conducted by Jiang and Probst [66], data were collected from a sample of approximately 24,000 people from various professional groups within 30 different countries. The results indicated that a direct relationship was found between individuals' perceptions of job insecurity and their burnout levels. The results of a study conducted by Katlav et al. [73] on tourist guides indicated that an increase in their perception of job insecurity is directly related to emotional exhaustion and desensitization but inversely related to a personal success factor. These study findings have suggested that the perception of job insecurity negatively affects individual burnout levels. Accordingly, it was considered that increases in the perception of job insecurity in tourism-sector employees increase their burnout levels, and the following $\mathrm{H} 2$ hypothesis was constructed.

Hypothesis 2 (H2). COVID-19-related job insecurity perception is positively correlated (negatively affect) with the burnout levels of hotel employees.

\subsection{The Moderating Role of Financial Well-Being}

There are several definitions in the literature regarding financial well-being, which was defined by McCarthy [74] as "having money and access to it", and based on the term of well-being, Joo [75] has explained it as a perception of an individual's situation of being financially free from anxiety, healthy, and happy, and Halleröd and Seldén [76] have approached it as a term related to how people assess their financial situations. A more current definition was provided by Brüggen et al. [77] as "the perception of being able to sustain current and anticipated desired living standard and financial freedom"; however, according to Panisch et al. [78], financial well-being does not reflect the collective sum of income, credit score, debt-to-income ratio, or investment profile but reflects numerous, interrelated factors, such as thoughts, positive and negative feelings, and behaviors related to finances.

The financial well-being status of individuals can be examined at various levels; however, it is possible to discuss this status based on the two groups of high and low financial well-being. Individuals with high financial well-being can easily meet their daily financial needs, and they have financial opportunities that make them resistant to economic shocks [79]. Individuals with low financial well-being have difficulty meeting their daily vital needs [80]. Changes in socioeconomic conditions have strong effects on individual 
health in every phase of life [81]. In fact, financial conditions are accepted as one of the most fundamental factors that affect in individual's health. The increase in financial concern that emerges as a result of a decline in financial well-being decreases an individual's healthrelated quality of life [78]. A high financial well-being enables individuals to be able to reach the resources they need to maintain their health [82].

Various studies have presented significant findings regarding the effects of low financial well-being on an individual's health. For example, low financial well-being, which is experienced as a result of being unemployed because of job insecurity, causes individuals to reduce their necessary expenditures for health protection, and the guarantee of social insurance as they become unemployed is removed [83]. On the other hand, financial stress is one of the most significant problems caused by low financial well-being, and the inability of reaching an income level to meet their needs causes financial stress [84] and negatively affects the individual's physical and mental health [85]. The underlying economic problems of financial stress cause disorders such as increased irritability, impatience, apathy, emotional distance, loss of professional enthusiasm, stomach ulcers, muscle tension, insomnia, headache, anxiety, and depression [86-88]. Burnout syndrome is considered an indirect outcome of psychological problems, such as anxiety and depression, and is one of the results of financial stress. According to Maslach et al. [89], burnout is a prolonged response to chronic emotional and interpersonal stressors on the job and is related to an individual's anxiety and depression levels. Although in very limited numbers, literature findings supporting this assumption can be found. The results of the study conducted by Verduzco-Gutierrez et al. [90] on female psychiatrists have suggested that financial stress increases personal dissatisfaction, career regret, and burnout syndrome. The results of the study conducted by Dündar et al. [91] on white-collar employees have suggested that a significant relationship was found between financial well-being and emotional burnout, desensitization, and burnout total scores, and have determined that there is no significant relationship between financial well-being and personal failure in general. The results of the study conducted by Sabri and Aw [92] on executives working within different sectors in Malaysia have suggested that when employees experience financial stress, they dedicate a significant part of their time and mental effort to cope with financial difficulties. In addition, it was suggested that this situation negatively affects their job satisfaction and physical and mental health and contributes to the development of burnout syndrome. Those findings suggest that low financial well-being negatively affects individual burnout levels. Accordingly, we considered that financial well-being has a mediator effect on COVID-19 anxiety levels and job insecurity perceptions for tourism-sector employees and their burnout levels, and hypotheses $\mathrm{H} 3, \mathrm{H} 3 \mathrm{a}$, and $\mathrm{H} 3 \mathrm{~b}$ were constructed.

Hypothesis 3 (H3). Low financial well-being is positively correlated (negatively affect) with the burnout levels of hotel employees.

Hypothesis 3a (H3a). The effect of COVID-19 anxiety on burnout differs according to financial well-being of hotel employees.

Hypothesis $\mathbf{3 b} \mathbf{b} \mathbf{H} \mathbf{3 b})$. The effect of job insecurity on burnout differs according to financial well-being of hotel employees.

\section{Methods}

\subsection{Data and Sample Procedure}

This research was conducted on five-star accommodations operating in Alanya and Manavgat, the most popular tourism destinations in Turkey. Because of the COVID19 pandemic, Turkey, like many countries, is passing through a difficult period. In 2019, Turkey ranked sixth in the list of the worlds' most popular tourist destinations and attracted 51.2 million foreign tourists. In 2020 , the number of visitors $(15,971,201)$ during the same 2019 period dropped by 69.14\% [93]. Data were collected between March and June 2021 
using an online questionnaire and a convenient sampling method. As the pandemic continued during the study, data were obtained using an online method to reduce the risk of infection. Because of the pandemic, not every hotel within the region remained open. The Turkish Ministry of Culture and Tourism required that accommodation facilities receive a "safe tourism certificate" to continue their operations during the pandemic. In this regard, 24 five-star accommodation facilities with a "safe tourism certificate" in the Alanya and Manavgat regions were first contacted by phone and given information about the study. Managers who agreed to contribute to the study directed their employees to the online questionnaire by sending e-mails and Whatsapp messages. No incentive was provided to the participants to complete the questionnaire. Although 24 accommodation facilities were interviewed at the beginning of the research, data could be collected from only the employees of 17 of these facilities. Because of having incomplete responses, 64 questionnaires were not included in the analyses. By the end of the study, 396 valid questionnaires were collected for a response rate of 53\% (396/750). To remove the risk of common method variance (CMV), participants were asked to not state their names on the questionnaires and were ensured that the data were kept confidential. The a priori sample size calculator was used for the structural equation models [94]. As a result of the calculation, a minimum sample size of 288 cases was needed (anticipated effect size $=0.3$, desired statistical power level $=0.95$, number of latent variables $=4$, number of observed variables $=26$ ). Based on this result, a sufficient sample size was used in the present study. Of the participants, $62 \%$ were male. A great majority of the participants were single (54\%), and they ranged in age from 19 to 51 years with a mean age of 29.73 years. Of the participants, $37 \%$ were catering-department employees, $26 \%$ were housekeeping employees, $12 \%$ were front office personnel, and $10 \%$ were employees within other departments. Employees were primarily high school (49\%) and primary school (28\%) graduates; $15 \%$ had associate degrees, and $8 \%$ had undergraduate degrees. Of the participants, $33 \%$ had been working in their current institutions $<1$ year, $47 \%$ worked in their current institutions for $1-5$ years, and $20 \%$ worked $\geq 6$ years.

\subsection{Measurements}

The research had two independent, one moderator, and one dependent variable. One independent variable, coronavirus anxiety, was measured using the coronavirus anxiety scale (CAS) developed by Lee [95]. The Turkish adaptation, validity, and reliability of the scale were conducted by Evren et al. [96]. CAS consists of five questions and one dimension. Each item was evaluated with a five-point-Likert-type scale from 0 (not at all) to 4 (nearly every day over the las two weeks) based on the experiences within the last 2 weeks. A CAS total score $\geq 9$ indicated probable dysfunctional coronavirus-related anxiety. The job insecurity scale (JIS), which was the other independent variable of the study, was used to measure employees' general perceptions about job insecurity during the COVID-19 pandemic. JIS developed by Pienaar et al. [54] comprised eight items. A higher scale score indicated a feeling of stronger job insecurity. Financial well-being that constitutes the moderator variable in the present study was measured using the three-item financial wellbeing scale (FWS) developed by Castro-González et al. [97]. FWS includes both individual indebtedness levels and financial concerns. Both JIS and FWS were created in English but were translated into Turkish, and the Turkish version was re-translated into English using the back-translation method to remove semantic shifts that could result. Translation and back-translation were conducted by two independent academic members who had received their graduate and Ph.D. degrees in the United States and United Kingdom. The burnout levels of the participants were evaluated using the COVID-19 burnout scale adapted by Yıldırım and Solmaz [50] from Malach Pine's [98] burnout measure short version. The COVID-19 burnout scale comprised 10 items; a higher score indicated a higher COVID-19 related burnout. Measurements for the last three scales mentioned above were based on five-point Likert scale with anchors ranging from 1 (strongly disagree) to 5 (strongly agree). The items involving negative meanings in the scales were reverse coded. In addition, 
questions to determine the demographic characteristics of the participants, such as age, sex, and education, etc., were included in the last section of the questionnaire.

\subsection{Data Analyses}

Descriptive statistics, CMV, measurement models, and hypothesis tests were conducted using SPSS 24.0 and SPSS AMOS 23 (IBM Inc., Armonk, NY, USA). Since the maximum probability is primarily used as a measurement estimation method and the analysis of a structural model, the assumption that the data were normally distributed was determined. Skewness and kurtosis values were analyzed to check whether the data displayed a normal distribution. Then, before the measurement model and hypothesis tests were conducted, we determined whether there were any missing or outlier values. Mahalanobis' distance was used to determine the extreme outliers; no outlier was found. Analyses regarding the research model were conducted in two steps as recommended by Anderson and Gerbing [99]. In the first step, the estimation model was tested using confirmatory factor analysis (CFA), and findings regarding the validity and reliability of the scale were obtained. The convergent validity and discriminant validity were then conducted to test whether the distinction of constructs in the research model was supported. To determine whether there was a CMV problem, the Harman's single factor test was applied, and CFA was conducted using a common latent factor. Data regarding demographic characteristics of the participants were examined through frequency and percentage distributions. The research hypotheses were tested using the structural equation model (SEM). The research model is presented on Figure 1.

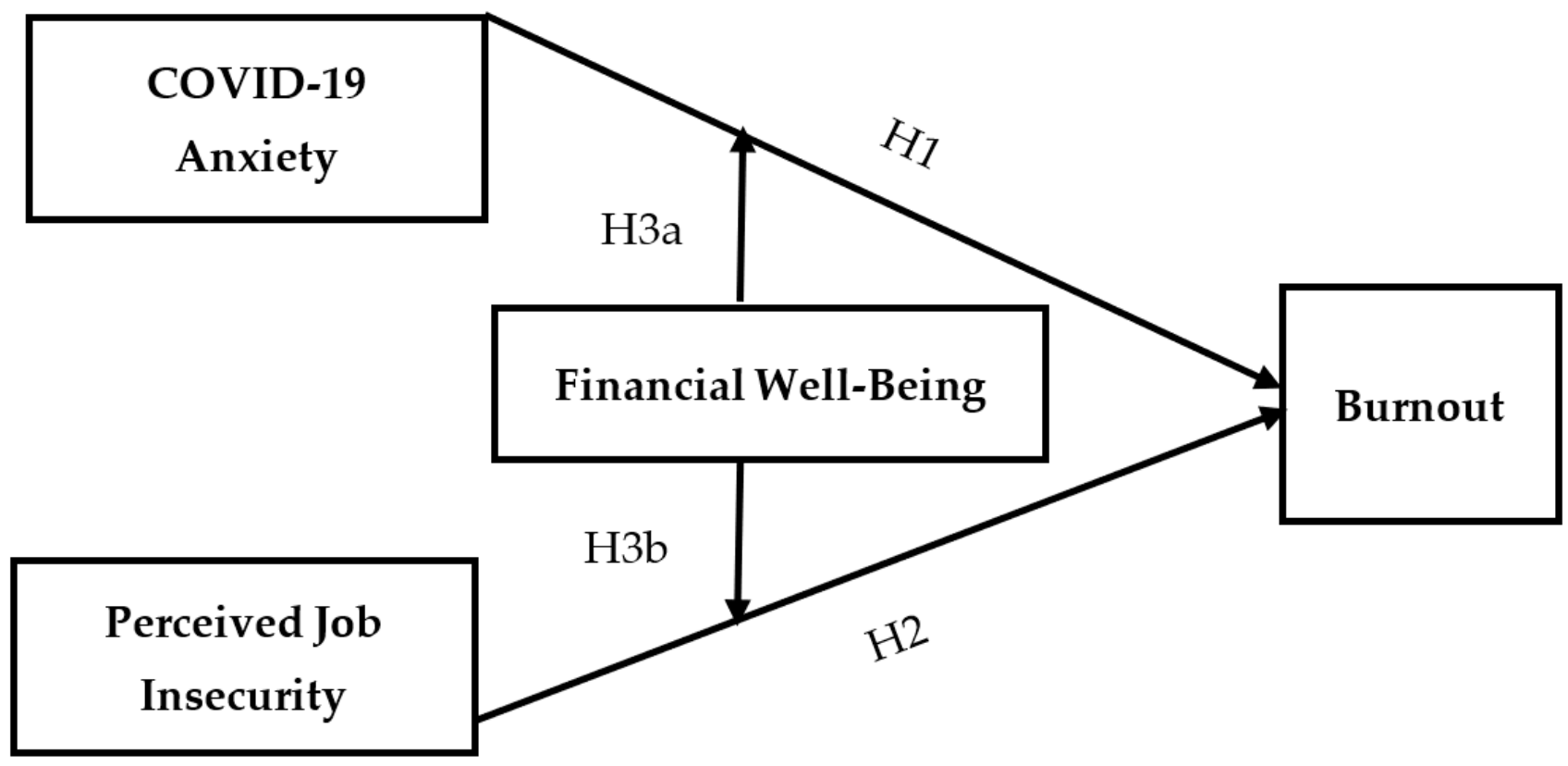

Figure 1. Research model.

\section{Findings}

\subsection{Measurement Model}

The measurement model used in the present study was tested using the confirmatory factor analysis with SPSS AMOS 23 (IBM Corp.). To examine the structure of the data collected and the distinctive validity of our structures, a two-step CFA was conducted as suggested by Anderson and Gerbing [99]. First, validity and reliability were analyzed for each of the scales constituting the measurement model, after which the effects between the structures in the model were tested. In this context, by using the maximum probability method, we used the alternative models strategy to determine whether the predicted 
structures of the scales were supported by the collected data. As shown in Table 1, we found that the estimated four-factors model was the one that best fit the data (model 4: $\left.\chi^{2} / \mathrm{df}=1.48, \mathrm{CFI}=0.987, \mathrm{RMSEA}=0.035, \mathrm{SRMR}=0.031, \mathrm{GFI}=0.924, \mathrm{CFI}=0.984\right)$ [100] The results of CFA conducted to test the overall measurement model are presented in Table 1. All factor loads of the scale items in Table 1 are $>0.70$ and have high $t$ values and were statistically loaded to the related latent variable in a significant way $(p<0.01)$ [101] The skewness and kurtosis values of the data took the values between -1.5 and +1.5 . Accordingly, it can be stated that the data were normally distributed to a large extent [102]. Statistical findings obtained indicated that the measurement model was acceptable. In addition, the measurement model of the study is presented in Figure 2.

Table 1. Results of the measurement model.

\begin{tabular}{|c|c|c|c|c|c|c|c|}
\hline Factors & Mean & SD & Estimate & S.E. & $t$ Value & Skewness & Kurtosis \\
\hline COVID-19 Anxiety & 1.49 & 1.04 & & & & & \\
\hline $\begin{array}{l}\text { I felt dizzy, lightheaded, or faint, when I read or listened to } \\
\text { news about the coronavirus }\end{array}$ & 1.37 & 1.24 & 0.883 & Fixed & & -0.058 & -0.251 \\
\hline $\begin{array}{l}\text { I had trouble falling or staying asleep because I was thinking } \\
\text { about the coronavirus. }\end{array}$ & 1.66 & 1.27 & 0.830 & 0.043 & $22.007 * * *$ & -0.157 & -0.894 \\
\hline $\begin{array}{l}\text { I felt paralyzed or frozen when I thought about or was exposed } \\
\text { to information about the coronavirus. }\end{array}$ & 1.61 & 1.15 & 0.806 & 0.044 & $20.561 * * *$ & -0.023 & -0.335 \\
\hline $\begin{array}{l}\text { I lost interest in eating when I thought about or was exposed to } \\
\text { information about the coronavirus }\end{array}$ & 1.51 & 1.17 & 0.837 & 0.048 & $21.946 * * *$ & -0.059 & -0.447 \\
\hline $\begin{array}{l}\text { I felt nauseous or had stomach problems when I thought about } \\
\text { or was exposed to information about the coronavirus. }\end{array}$ & 1.35 & 1.16 & 0.850 & 0.046 & $22.535 * * *$ & -0.084 & -0.580 \\
\hline Perceived Job Insecurity & 3.44 & 0.96 & & & & & \\
\hline I worry about the continuation of my career & 3.30 & 1.12 & 0.920 & Fixed & & 0.109 & -0.518 \\
\hline I am certain/sure of my job environment & 3.43 & 1.11 & 0.895 & 0.032 & $29.602 * * *$ & 0.004 & -0.694 \\
\hline I am very sure that I will be able to keep my job & 3.46 & 1.16 & 0.881 & 0.035 & $28.113^{* * *}$ & 0.050 & -0.143 \\
\hline I think that I will be able to continue working here & 3.49 & 1.08 & 0.870 & 0.037 & 27.106 & 0.087 & -0.375 \\
\hline I fear that I might get fired & 3.47 & 1.13 & 0.793 & 0.039 & $22.025 * * *$ & 0.381 & -0.485 \\
\hline I fear that I might lose my job & 3.45 & 1.10 & 0.809 & 0.041 & $22.838^{* * *}$ & 0.046 & -0.984 \\
\hline There is only a small chance that I will become unemployed & 3.45 & 1.06 & 0.775 & 0.041 & $21.025 * * *$ & 0.121 & -0.669 \\
\hline I feel uncertain about the future of my job & 3.47 & 1.08 & 0.848 & 0.038 & $25.363^{* * *}$ & 0.090 & -0.751 \\
\hline Financial Well-Being & 2.76 & 0.99 & & & & & \\
\hline I tend to worry about paying my normal living expenses & 2.65 & 1.11 & 0.924 & Fixed & & -0.016 & -0.899 \\
\hline I have too much debt right now & 2.84 & 1.08 & 0.844 & 0.040 & $23.430 * * *$ & -0.315 & -0.614 \\
\hline I pay my bills on time & 2.81 & 1.05 & 0.880 & 0.039 & $25.751 * * *$ & -0.310 & -0.708 \\
\hline Burnout (When I think about COVID-19 overall) & 3.52 & 0.74 & & & & & \\
\hline I often feel tired & 3.40 & 0.90 & 0.872 & Fixed & & -0.205 & -0.769 \\
\hline I often feel disappointed with people & 3.70 & 0.98 & 0.873 & 0.045 & $24.300 * * *$ & -0.161 & -1.00 \\
\hline I often feel hopeless & 3.51 & 0.89 & 0.819 & 0.047 & $21.378^{* * *}$ & -0.145 & -0.941 \\
\hline I often feel trapped. & 3.57 & 0.93 & 0.818 & 0.049 & $21.284 * * *$ & -0.071 & -0.911 \\
\hline I often feel helpless & 3.53 & 0.92 & 0.776 & 0.049 & $19.556^{* * *}$ & 0.041 & -1.16 \\
\hline I often feel depressed & 3.58 & 0.89 & 0.792 & 0.050 & $20.202 * * *$ & 0.434 & -1.05 \\
\hline I feel physically weak/sickly & 3.53 & 0.93 & 0.727 & 0.053 & $17.581 * * *$ & 0.387 & -0.920 \\
\hline I often feel worthless/like a failure & 3.44 & 0.89 & 0.771 & 0.049 & $19.265^{* * *}$ & 0.229 & -0.874 \\
\hline I often feel difficulties sleeping & 3.46 & 0.90 & 0.716 & 0.057 & $17.172 * * *$ & 0.277 & -0.924 \\
\hline I often feel "I've had it" & 3.46 & 0.83 & 0.802 & 0.048 & $20.614^{* * *}$ & 0.173 & -1.28 \\
\hline
\end{tabular}

Notes: COVANX = COVID-19 anxiety; PERJINS = perceived job insecurity; FINWLBNG = financial well-being; SD = std. deviation; $* * * p<0.001$

As shown in Table 2, three alternative models (three factors, two factors, and one factor) of the predicted four-factor model were compared using the $\chi^{2}$ difference tests.

\subsection{Convergent and Discriminant Validity}

Convergent and discriminant validity are two significant indicators of structure validity. To evaluate convergent validity, AVE and CR values of the structures in the measurement tool were calculated, while MSV and ASV values of the structures in the measurement tool were calculated to evaluate discriminant validity. To ensure convergent validity, dimensions of the measurement model were suggested to be AVE $>0.50$, $\mathrm{CR}>0.70$, and $\mathrm{CR}>\mathrm{AVE}$; and for discriminant validity, these dimensions were suggested to be MSV < AVE, ASV < AVE, and $\sqrt{ }$ AVE $>$ correlations among the constructs $[103,104]$. $\mathrm{CR}, \mathrm{AVE}, \mathrm{MSV}, \mathrm{ASV}$, and the correlation values of all factors are presented in Table 3 , which shows AVE values $>0.50, \mathrm{CR}$ values $>0.70$, and AVE values $<C R$ values and indicates that the factors have convergent validity [105]. The factors' AVE values > MSV, ASV values, and $\sqrt{ }$ AVE values of factors higher than the crossfactorial correlation indicate that factors have discriminant validity [106]. The Cronbach's $\alpha$ values of all factors were $>0.70$, which indicated that they had strong reliability values [105]. According to the results of the correlation analyses on Table 3, COVID-19 anxiety was positively correlated with the risk 
perception of job insecurity $(\mathrm{r}=0.250, p<0.001)$ and burnout $(\mathrm{r}=0.442, p<0.001)$. The risk perception of job insecurity was negatively correlated with financial well-being $(\mathrm{r}=-0.496$, $p<0.001)$ but was positively correlated with burnout $(\mathrm{r}=0.594, p<0.001)$. Financial well-being was negatively correlated with burnout $(\mathrm{r}=-0.561, p<0.001)$.

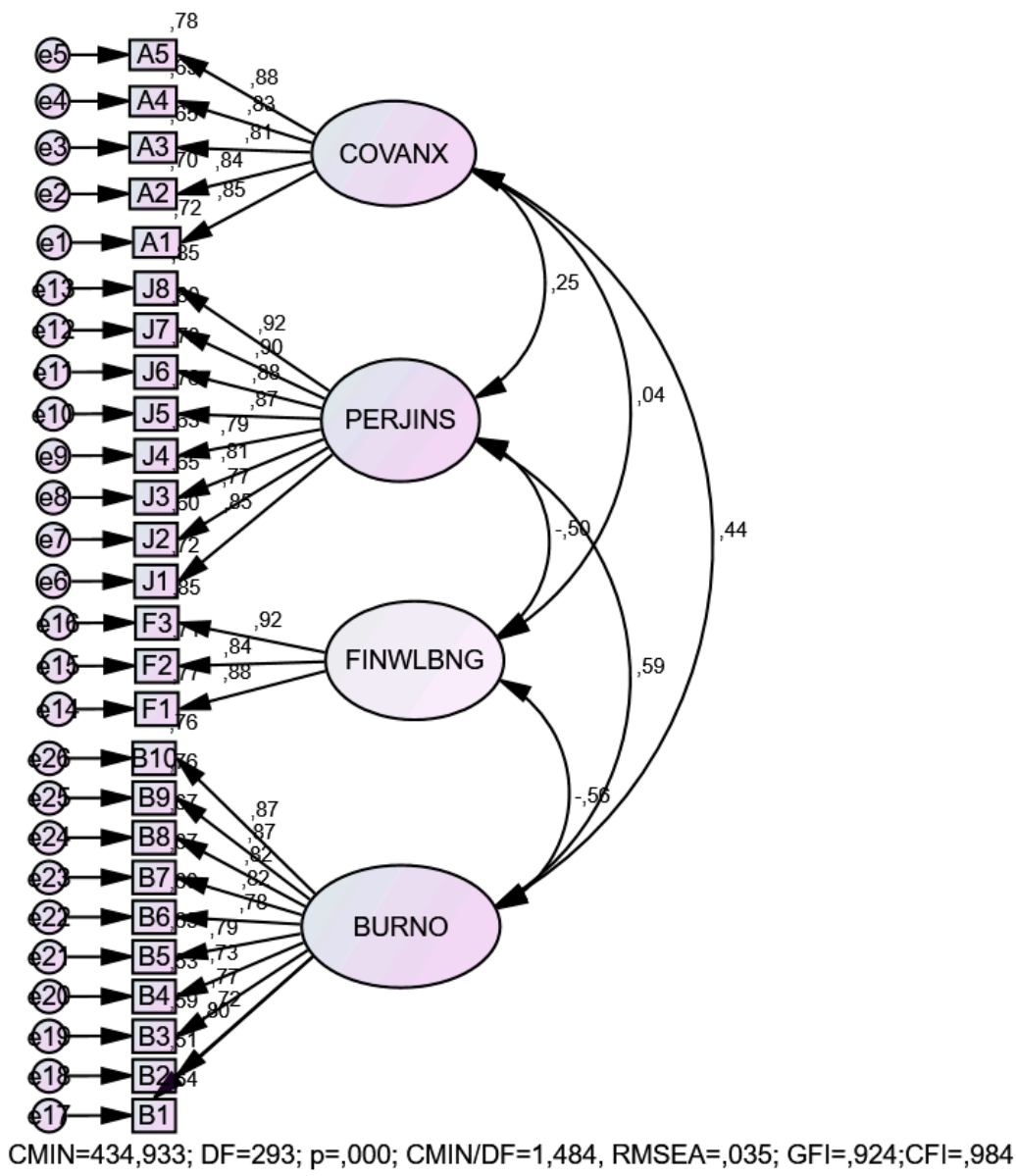

Figure 2. The measurement model.

Table 2. Goodness of fit values of models.

\begin{tabular}{|c|c|c|c|c|c|c|c|c|c|c|}
\hline \multirow{2}{*}{ Model } & \multirow{2}{*}{$\mathrm{X}^{2}$} & \multirow{2}{*}{ df } & \multirow{2}{*}{$X^{2} / \mathrm{df}$} & \multirow{2}{*}{ CFI } & \multirow{2}{*}{ SRMR } & \multirow{2}{*}{ RMSEA } & & \multicolumn{3}{|c|}{ Model Comparison } \\
\hline & & & & & & & & $\Delta X^{2}$ & $\Delta \mathrm{df}$ & $\mathrm{p}\left(\Delta \mathrm{X}^{2}\right)$ \\
\hline Four factors ${ }^{a}$ & 434.93 & 293 & 1.48 & 0.984 & 0.031 & 0.035 & & - & - & \\
\hline Three factors ${ }^{b}$ & 1191.49 & 296 & 4.02 & 0.896 & 0.080 & 0.088 & 2 vs. 1 & 756.56 & 3 & 0.000 \\
\hline Two factors ${ }^{c}$ & 2591.48 & 298 & 8.69 & 0.735 & 0.152 & 0.140 & 3 vs. 1 & 215.55 & 5 & 0.000 \\
\hline One factor ${ }^{d}$ & 4107.09 & 299 & 13.73 & 0.560 & 0.152 & 0.180 & 4 vs. 1 & 3672.16 & 6 & 0.000 \\
\hline
\end{tabular}

Notes: ${ }^{a}=$ COVID-19 anxiety, perceived job insecurity, financial well-being, burnout; ${ }^{b}=$ COVID-19 anxiety, burnout, perceived job insecurity + financial well-being; ${ }^{\mathrm{c}}=$ perceived job insecurity, financial well-being, COVID-19 anxiety + burnout; ${ }^{\mathrm{d}}=$ COVID-19 + anxiety + perceived job insecurity + financial well-being + burnout.

Table 3. Convergent and discriminant validity.

\begin{tabular}{cccccccccc}
\hline & $\mathbf{1}$ & $\mathbf{2}$ & $\mathbf{3}$ & $\mathbf{4}$ & $\boldsymbol{\alpha}$ & AVE & CR & MSV & ASV \\
\hline (1) COVANX $^{2}$ & $(0.841)^{\mathrm{a}}$ & & & & 0.923 & 0.708 & 0.924 & 0.195 & 0.087 \\
(2) PERJINS & $0.250^{* *}$ & $(0.850)^{\mathrm{a}}$ & & & 0.954 & 0.723 & 0.954 & 0.353 & 0.220 \\
(3) BURNOUT & $0.442^{* *}$ & $0.594^{* *}$ & $(0.798)^{\text {a }}$ & & 0.945 & 0.637 & 0.946 & 0.353 & 0.288 \\
$(4)$ FINWLBNG & 0.041 & $-0.496^{* *}$ & $-0.561^{* *}$ & $(0.883)^{\text {a }}$ & 0.913 & 0.780 & 0.809 & 0.315 & 0.187 \\
\hline
\end{tabular}

Notes: COVANX = COVID-19 anxiety; PERJINS = perceived job insecurity; FINWLBNG = financial well-being; $\alpha=$ Cronbach, $^{\mathrm{a}}=$ square root of the $\mathrm{AVE},{ }^{* *} p<0.01$. 


\section{3. $C M V$ Evaluation}

In empirical research that examines attitude-behavior relations, a CMV problem may occur from collecting dependent and independent data from the same respondent at the same time using the same method. CMV may indicate the correlation between variables as higher or lower than the actual correlation $[107,108]$. In the present study, procedural operations were applied to prevent the CMV problem, and statistical analyses were conducted after collecting the data to check whether CMV existed [109]. Procedurally, in the questionnaire, the participants were informed that responses would be kept confidential and would be evaluated by only the researchers; the data provided definitely would not be shared with any person or institution; and the information would be used only in scientific journals. In addition, items for dependent, moderating, and independent variables were scattered within the questionnaire [110]. By implementing these procedural precautions, we aimed to reduce the respondents' item priming effects [109]. Although we attempted to prevent the CVM problem through the explanation given on the questionnaire and differentiation of the scale priorities, determining a CVM problem was statistically checked using Harman's single-factor test. Harman's single-factor test is one of the most commonly used techniques used to determine a CVM problem. This method loads all items from each of the constructs into an exploratory factor analysis (EFA) to determine whether one single factor emerges or one general factor accounts for a majority of the covariance among the measures [110]. As a result of EFA, four factors with a latent value $\geq 1(\lambda \leq 1)$ were determined. The first factor explained $25.59 \%$ of total variance, a value $<50 \%$ of the threshold, which indicated that there was no CMV problem. In addition, single-factor CFA is used to test whether there is any CFA problem [109]. A poor fitness of the single-factor model with CFA $\left(\chi^{2} / \mathrm{df}=13.73, \mathrm{CFI}=0.560, \mathrm{RMSEA}=0.42\right.$, SRMR $\left.=0.151\right)$ asserts that there is no CVM problem. Second, to determine CMV, confirmatory factor analyses were conducted using a common latent factor as a more sensitive and reliable method [107]. A model was tested in which the observed variables of the four-factor research model was loaded both on their own theoretical latent factors and on a common method factor. The model with the latent factor fit the data $\left(\chi^{2} / \mathrm{df}=1.408, \mathrm{CFI}=0.987\right.$, RMSEA $=0.032$, SRMR $=0.023$ ), and the obtained results indicated that the common method bias is not a serious problem to prevent our hypotheses' sufficiency test [111].

\subsection{Hypothesis Testing}

For the employees within the accommodation sector, a path analysis was conducted using SPSS AMOS 24 (IBM Inc.) to test the moderator role of financial well-being on the effect of the COVID-19 fear and job insecurity perception on burnout. The maximum likelihood calculation method was used in the path analysis conducted with the observed variables. The results of the path analysis are presented in Table 4 . Before the analysis, the values of the predictor variables and the moderator variable were standardized. According to the results presented in Table 4, all predictor variables included in the path analysis explained $54.5 \%$ of the change in burnout $\left(R^{2}=0.545, p<0.01\right)$. The independent variables of COVID-19 anxiety ( $\beta=0.323, p<0.01$ ) and job insecurity perception $(\beta=0.306, p<0.01)$ predicted burnout at a positive and significant level. These results indicated that the $\mathrm{H} 1$ and $\mathrm{H} 2$ hypotheses were supported. The moderator variable of financial well-being $(\beta=-0.425$, $p<0.01)$ negatively and significantly affected burnout. We determined that both COVID-19 fear and financial well-being $(\beta=0.251, p<0.01)$ and job insecurity perception and financial welfare $(\beta=-0.204, p<0.01)$ have a significant and interactional effect on burnout. This outcome indicated that the H3 hypothesis was supported.

The effects of the moderator variable are graphically presented in Figure 3. Examining the moderator variable in detail, the effect of both of the COVID-19 and job insecurity perceptions on burnout differs whether the financial well-being is high or low. As can be seen in Figure 4., in the case of high financial well-being, we determined that the effect of COVID-19 anxiety on burnout significantly increased ( $\beta=0.550, t=7,98, p<0.01$ ); however, in the case of low financial well-being, the effect was not significant on burnout 
( $\beta=0.096, t=1.35, p>0.05)$. These findings supported the H3a hypothesis. The effect of job insecurity on burnout differs according to an employee's financial status. With high financial well-being, the perception of job insecurity did not have a significant effect on burnout ( $\beta=0.091, t=1,32, p>0.05)$; however, with low financial well-being, the perception of job insecurity had a significant negative effect on burnout $(\beta=0.521, t=7.30, p<0.01)$. These findings supported the H3b hypothesis. According to these results, although the COVID-19 anxiety did not have any significant effect on burnout, the perception of job insecurity had a significant negative effect on burnout in employees with low financial well-being. In those with high financial well-being, the perception of job insecurity did not create any significant effect on burnout; however, the COVID-19 anxiety had a significant effect. These results indicated that the effect of the COVID-19 anxiety and the perception of job insecurity on burnout was moderated by financial well-being.

Table 4. Results of path analysis to indicate the moderator effect $(n=396)$.

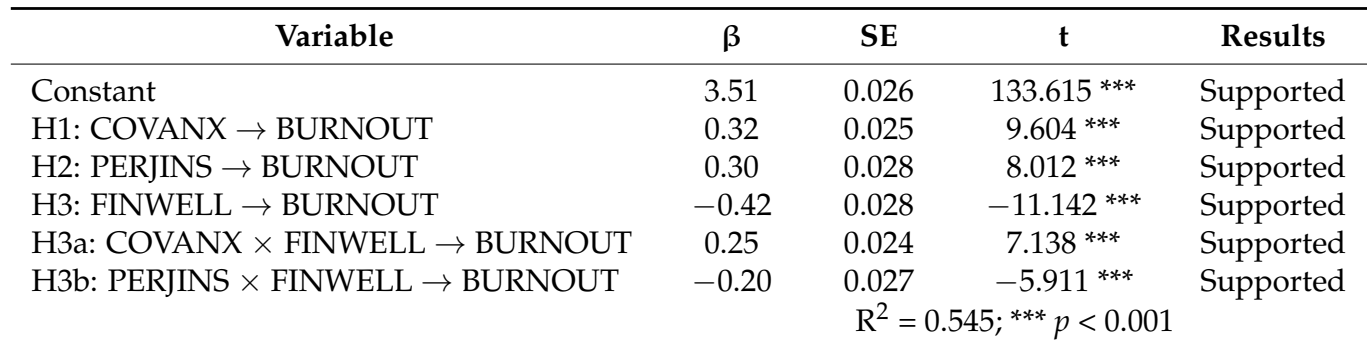

Notes: COVANX = COVID-19 anxiety; PERJINS = perceived job insecurity; FINWLBNG = financial well-being.
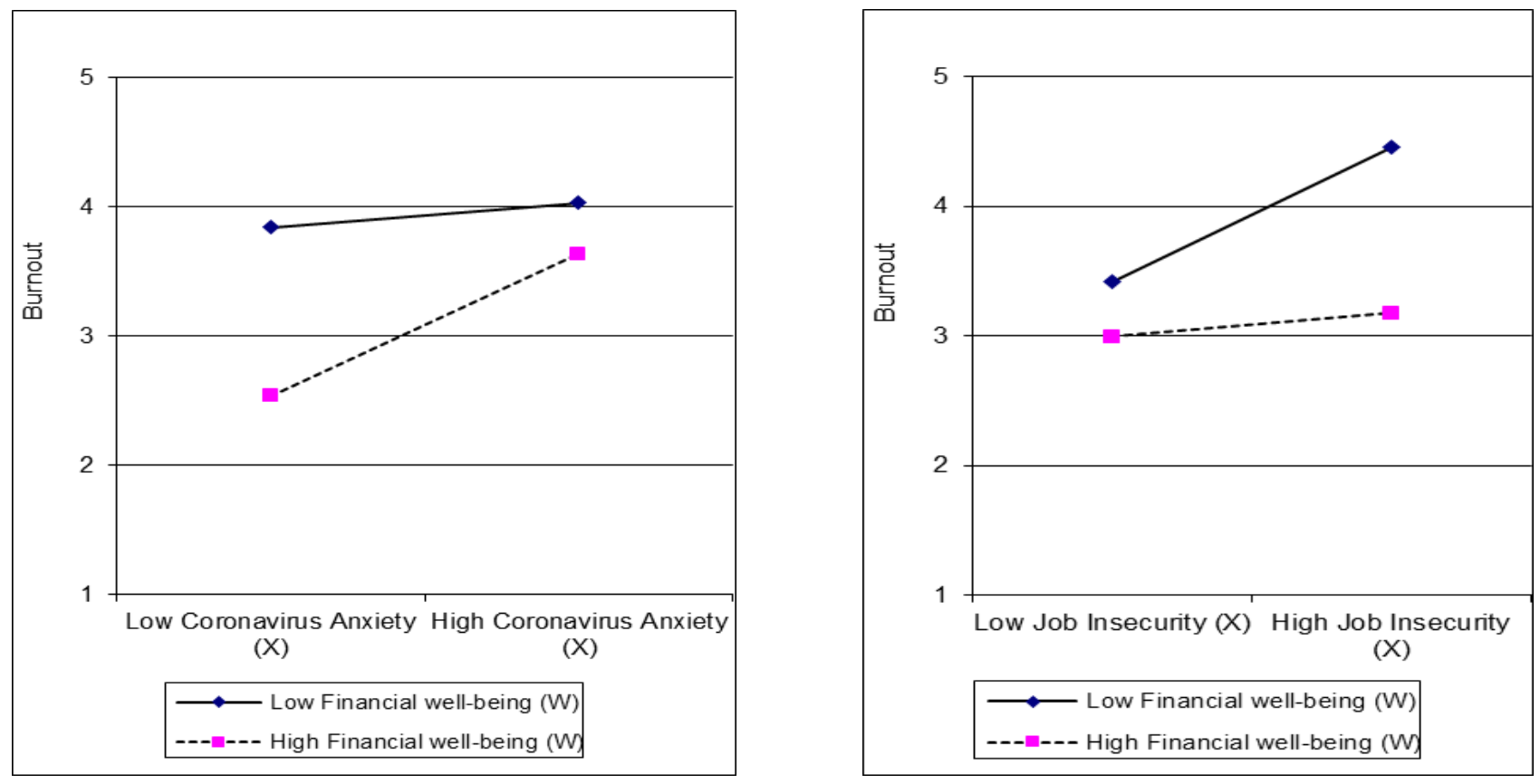

Figure 3. Moderating effect of financial well-being. 


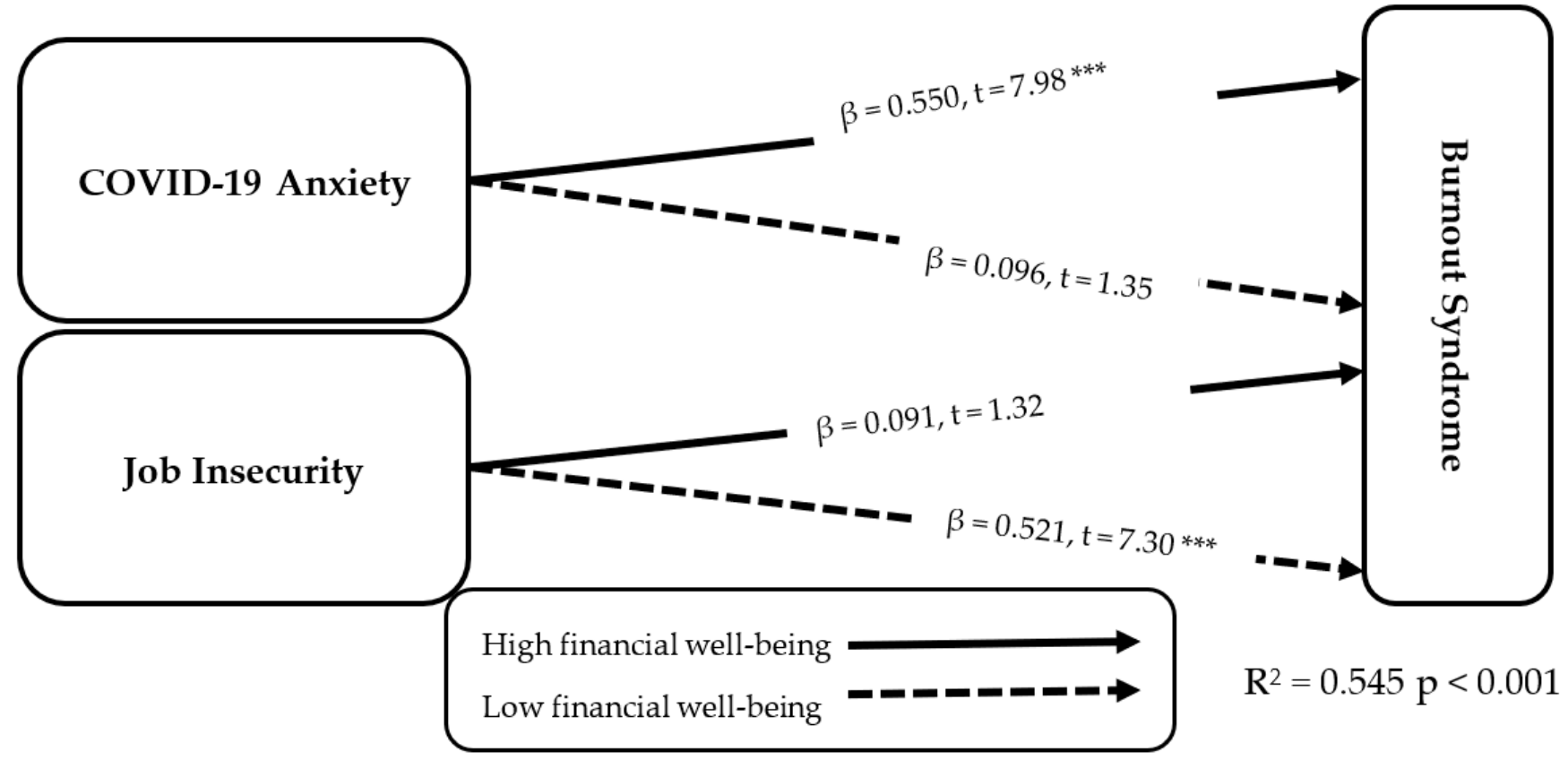

Figure 4. Result of conceptual model.

\section{Discussion}

The present study was initially aimed at determining the effect of the COVID-19 anxiety and job insecurity on burnout. Our results were consistent with those of previous studies [48-51,66,69-73] and indicated that the COVID-19 anxiety and job insecurity perception had negative effects on employee burnout levels. Job insecurity is accepted as one of the most powerful stress factors that affect emotional burnout [112]. In the present study, we determined that COVID-19-based job insecurity perception negatively affected burnout. In their research, Yu et al. [11] have asserted that hotel employees are worried about financial losses because of job insecurity and unpaid leaves because the COVID-19 pandemic caused the tourism industry to cease operations. Financial loss and job insecurity are seen as COVID-19-related long-term stress sources; therefore, this situation can transform a negative effect on an employee's mental health into a destructive one [18]. In their research conducted in China, Zhang et al. [17] have determined that people who stop working during the COVID-19 pandemic have worse health problems, more psychological distress, and less life satisfaction than people who continue work. Similar results were found in other research, which have asserted that worldwide crises cause unemployment problems and negative effects on an employee's mental and psychological health [113-115].

The second main objective of the present study was to determine whether the effect of the COVID-19 anxiety and job insecurity on burnout differed in terms of the employee's financial well-being. The results obtained suggested that the effect of the COVID-19 anxiety and job insecurity on burnout significantly differed in terms of an individual's financial well-being, which constituted one of the important findings of the research. When an individual had high financial well-being, the COVID-19 anxiety was effective on burnout; however, it did not have a statistically significant effect on those with low financial wellbeing. A more different outcome was observed in the effect of job insecurity on burnout. For the individuals with high financial well-being, job insecurity did not have a significant effect on burnout, while for those with low financial well-being, job insecurity was directly correlated and had a negative effect on burnout. These results suggest that the effect of the COVID-19 anxiety and job insecurity on burnout significantly differ depending on whether an individual's financial well-being is high or low. These results indicated that the effect of the COVID-19 anxiety and job insecurity perception on burnout is moderated by financial well-being. During the COVID-19 process, an employee's anxiety of becoming 
unemployed can be seen as a potential loss of their significant resources, which may predict burnout at a significant level [12]. The thought of losing one's current job or being unable to enter the job market consumes the psychological resources of the employee; therefore, it affects his or her mental health, particularly during hard times. In brief, job insecurity and the fear of being unable to be employed during a crisis negatively affect the mental health of the employees [112]. Hamouche [18] had determined that the COVID-19 pandemic negatively affects an employee's mental health. The COVID-19-related infection risk, financial loss, and job insecurity were determined to be stress factors on employees. Lam et al. [116] have conducted a study on casino employees in Macao (China) and determined that job insecurity causes psychological disorders, such as depression, anxiety, and stress. In particular, financially poor people with low incomes are highly affected by the fear of being unable to be employed, which creates negative mental and healthcare problems for them [16]. Financial problems and insufficiencies are strong predictors of depression, while financial well-being increases subjective well-being [117]. In the study by Mucci et al. [118] in which that they examined the relationship between stress and economic crisis, their results have indicated that crises are a significant stress factor that negatively affect an employee's welfare and mental health. In their research, Mucci et al. [118] have concluded that certain situations, such as the rise in unemployment, increase in workload, and reduction in wages after a crises, are related to mood disorders, anxiety, depression, and suicide rates. In addition, in times of economic crises, employees' own economic status may directly affect how they perceive their mental health [119]. Low-level fears about the economic situation and believing that one is capable of attaining new employment may enable individuals to maintain mental health during austere times. In the research conducted on employees working in an Italian organization, Giorgi et al. [120] have asserted that fear of economic crisis and perceived low employability are positively associated with psychological distress. Low financial well-being is included among the factors that negatively affect employees' mental health [121]. One of the top contributors to psychosocial stress is financial insecurity because basic living conditions are built upon the management of personal financial resources [25]. In the present study, we suggested that individuals with low financial well-being were affected more from the fear of being unemployed during the COVID-19 pandemic, and that their burnout levels were higher than that in individuals with high financial well-being. This finding indicated that financial well-being helps individuals to protect their mental health during difficult times.

\section{Theoretical and Managerial Implications}

Because the hotel industry is labor intensive, employees play vital roles to provide customer satisfaction and qualified services. It is not possible for a hotel to provide services to their customs without healthy employees, and frontline employees were more important during the pandemic than during any other time [16]. The results of the present study help to better understand how pandemics, which deeply affect the hotel industry and affect employees' psychological status, and guide decision makers in maintaining their employees' psychological health during the same situations.

Work within the hotel industry is very difficult and stressful [122], and during the COVID-19 process, hotel employees had to continuously manage their negative feelings and exhibit a positive outlook to their guests, which increased the possibility of experiencing burnout syndrome $[123,124]$; consequently, although emotional burnout was widely examined in the accommodation industry, individual differences from the emotional burnout experience were not fully examined [26]. The present study contributed to filling that aforementioned gap. We determined that as an individual characteristic, financial well-being was a factor that significantly affected the severity of the effect of the COVID-19 anxiety and job insecurity on burnout. The findings obtained contributed to the COR theory, which asserts that financial well-being is a sense of security against stress [125] while low financial well-being is considered to be a personal stress factor [126]. According to the COR theory, stress and burnout can emerge when the threat of losing 
resources is perceived or when the resources are lost [127]. Other research findings and theoretical arguments have indicated that institutional-, regional-, and international-level economic situations may affect a worker's perceptions, attitudes, behaviors, and general welfare [120]. According to the COR theory, employment and job security are significant resources [128]. According to the research findings, as financial well-being decreases, the effect of the concern over unemployment on burnout significantly increases.

The JD-R is a functional model that evaluates a worker's well-being [24], and our findings contributed to the JD-R model. According to this model, although the employees were devoted to their organizations, as long as the concern about COVID-19 and the pandemic-related job insecurity continue, it is possible for them to have psychologically negative emotions and thoughts. When job demands are higher than the skill level of the employee, they can experience burnout syndrome [129]. According to the JD-R model theory, particularly during crisis periods when organizations are negatively affected, job security is a significant source by which to reduce the possible negative effects of job demands. In their research conducted within the context of the JD-R model, Xanthopoulou et al. [130] have indicated that employees who have more individual resources are more resistant to the negative effects of job demands.

Health and security are both basic needs for employees and basic human rights; therefore, it is necessary to be protected from the risk elements that threaten health and safety in a working environment [131]. Increasing an employee's social, psychological, and professional well-being to the maximum extent possible is among the basic obligations of any organization. In this regard, decision makers should create a working environment that would prevent the risk of COVID-19 spread, provide the necessary materials to protect employees from the virus (mask, disinfectant, etc.), and should educate and inform employees about the pandemic. In addition, it is important to ensure that the customers comply the instructions of WHO to provide a safe and healthy environment for the employees. In their research conducted on hotel employees, Üngüren and Koç [132] have determined that in terms of occupational health and safety criteria, a colleague's level of awareness and consciousness about occupational health and safety and the administrative measures and precautions about occupational health and safety have positive effects on organizational trust. Informing employees in a transparent way regarding the employment policy that is followed by the organization during a pandemic contributes to reducing uncertainty about job insecurity. For example, Accor, which had to close two thirds of its hotels worldwide during the COVID-19 pandemic, dedicated to allocating 25\% of the planned dividend payout of $\$ 87.07$ million to a fund dedicated to employees [6]. Coronaviruses causing respiratory infections were first discovered in the 1960s, and we must remember that they emerged during various times and in various countries as SARS-CoV; Middle East respiratory syndrome (MERS)-CoV; and human coronavirus 229Ei (HCoV-229E), OC43, NL63, and HKU1 and caused several diseases [11]. With ongoing new contagious diseases, it is possible to continue to observe new epidemic diseases going forward. In this regard, both policy makers and business managers should work together and take precautions to reduce the negative effects of any possible difficulties.

\section{Conclusions}

Research indicates that because the COVID-19 virus spreads very easily through close contact and because of the high death ratio, people are concerned about becoming infected [133-135]. Hotel-sector employees have a remarkably high risk of becoming infected because they have close physical contact with customers; therefore, they may experience high stress and exhaustion [48]. The results of the research conducted by Yu et al. [11] using qualitative and quantitative methods suggested that because hotel employees are in close contact with various customers, they have a perception of a risk of becoming infected, which causes them to have serious mental stress. For hotel-sector employees, the only problem that resulted from the pandemic was their concerns regarding health. On the other hand, the economic need for people to sustain their lives should also 
be perceived as an important problem. One of the chronic problems in the tourism sector is job insecurity, which became a more difficult issue during the pandemic, such that, on the one hand, hotel-sector employees were afraid of health problems, even fear of death, but on the other hand, they were afraid of being devoid of economic resources to meet their vital needs. At this point, the issue of job insecurity became an extreme devastating factor. In this context, we measured the impact of COVID-19 anxiety and job insecurity perceptions on the burnout levels of hotel industry employees during the pandemic and tested the moderator role of employees' financial well-being. As a result of analysis, we determined that both the anxiety of COVID-19 and the perception of job insecurity in the pandemic process increase the burnout of the employees. As a more detailed result of the research, we found that the impact of COVID-19 anxiety and job insecurity on burnout differs significantly according to the financial well-being of employees. COVID-19 anxiety influences the burnout levels of employees with high financial well-being, while the perception of job insecurity influences the burnout levels of employees with low financial well-being. In other words, financial well-being plays a moderator role in the effect of COVID-19 anxiety and job insecurity perception on burnout. These results are important for better understanding the problems experienced by hotel industry employees during the pandemic process and the conditions they can cope with.

\section{Limitations and Future Recommendations}

In the present study, the factors that affect burnout levels of hotel-sector employees were evaluated within the context of the fear of contracting COVID-19 and personal factors, such as the perception of pandemic-related unemployment and financial well-being rather than in an institutional context. To conclude, the effect of the fear of contracting the disease that occurred as a result of the global pandemic and the effect of the fear of losing one's job on burnout was discussed with regard to the employees' financial well-being. Within the framework of the JD-R model [136], as long as job demands and job resources are balanced with each other, employees' job stress decreases and their well-being increases; therefore, for future research, it is recommended that in addition to the external factors and personal characteristics, the organization's policies during a crisis and its support for its employees and the decision makers' attitudes and behaviors should also be addressed when determining the effects on employee mental health. It was determined that unions worked very effectively during the COVID-19 pandemic to resolve job health and security issues [137]. In this regard, conducting studies to examine the hotel employees who are and are not union members contributes to an understand of the effect and importance of the unions during times of crises. In addition, studies in several countries have indicated that job security is perceived to be higher within the public sector than within the private sector [122]; therefore, public- and private-sector employees can be compared to more clearly understand the importance of job security during times of crisis. One of the limitations of this research was that it was conducted on employees in the hotels that were open during the pandemic; therefore, individuals who were unable to find a job because of a low demand or who were not working because their hotels had closed were not included in the study. Another limitation of the study was that it was conducted on employees who worked in five-star hotels whose customers were mostly foreign tourists.

Author Contributions: Conceptualization: E.Ü. and Ö.A.T.; methodology: E.Ü., Ö.A.T., H.A. and Y.Y.K.; software, E.Ü. and Ö.A.T.; validation, E.Ü., Ö.A.T., H.A. and Y.Y.K.; formal analysis, E.Ü. and Ö.A.T.; investigation: E.Ü., Ö.A.T., H.A. and Y.Y.K.; resource: E.Ü. and Ö.A.T.; data curation: E.Ü., Ö.A.T., H.A. and Y.Y.K.; writing-original draft preparation: E.Ü. and Ö.A.T.; writing-review and editing: E.Ü., Ö.A.T., H.A. and Y.Y.K.; All authors have read and agreed to the published version of the manuscript.

Funding: No funding was received for this research.

Institutional Review Board Statement: Not applicable. 
Informed Consent Statement: Informed consent was obtained from all subjects involved in the study.

Data Availability Statement: The data presented in this study are available on request from the corresponding author.

Conflicts of Interest: The authors declare no conflict of interest.

\section{References}

1. Jung, H.S.; Jung, Y.S.; Yoon, H.H. COVID-19: The effects of job insecurity on the job engagement and turnover intent of deluxe hotel employees and the moderating role of generational characteristics. Int. J. Hosp. Manag. 2021, 92, 102703. [CrossRef]

2. Gössling, S.; Scott, D.; Hall, C.M. Pandemics, tourism and global change: A rapid assessment of COVID-19. J. Sustain. Tour. 2020, 29, 1-20. [CrossRef]

3. Zheng, D.; Luo, Q.; Ritchie, B.W. Afraid to travel after COVID-19? Self-protection, coping and resilience against pandemic 'travel fear'. Tour. Manag. 2021, 83, 104261. [CrossRef]

4. Pine, R.; McKercher, B. The impact of SARS on Hong Kong's tourism industry. Int. J. Contemp. Hosp. Manag. 2004, 16, 139-143. [CrossRef]

5. Min, J. The Effect of the SARS Illness on Tourism in Taiwan: An Empirical Study. Int. J. Manag. 2005, 22, 497-506.

6. Nhamo, G.; Dube, K.; Chikodzi, D. Impacts and Implications of COVID-19 on the Global Hotel Industry and Airbnb. In Counting the Cost of COVID-19 on the Global Tourism Industry; Springer International Publishing: Cham, Switzerland, 2020; pp. 183-204. [CrossRef]

7. Khan, A.; Bibi, S.; Lyu, J.; Latif, A.; Lorenzo, A. COVID-19 and sectoral employment trends: Assessing resilience in the US leisure and hospitality industry. Curr. Issues Tour. 2020, 24, 1-18. [CrossRef]

8. Pearlman, D.; Melnik, O. Hurricane Katrina's Effect on The Perception of New Orleans Leisure Tourists. J. Travel Tour. Mark. 2008, 25, 58-67. [CrossRef]

9. World Health Organization (WHO). Modes of Transmission of Virus Causing COVID-19: Implications for IPC Precaution Recommendations. 2020. Available online: https://apps.who.int/iris/bitstream/handle/10665/331601/WHO-2019-nCoV-Sci_ Brief-Transmission_modes-2020.1-eng.pdf. (accessed on 12 May 2021).

10. Teng, Y.-M.; Wu, K.-S.; Lin, K.-L.; Xu, D. Mental Health Impact of COVID-19 on Quarantine Hotel Employees in China. Risk Manag. Healthc. Policy 2020, 13, 2743-2751. [CrossRef]

11. Yu, J.; Park, J.; Hyun, S.S. Impacts of the COVID-19 pandemic on employees' work stress, well-being, mental health, organizational citizenship behavior, and employee-customer identification. J. Hosp. Mark. Manag. 2021, 30, 529-548. [CrossRef]

12. Vo-Thanh, T.; Vu, T.-V.; Nguyen, N.P.; Van Nguyen, D.; Zaman, M.; Chi, H. COVID-19, frontline hotel employees' perceived job insecurity and emotional exhaustion: Does trade union support matter? J. Sustain. Tour. 2021, 1-18. [CrossRef]

13. Khalid, I.; Khalid, T.J.; Qabajah, M.R.; Barnard, A.G.; Qushmaq, I.A. Healthcare Workers Emotions, Perceived Stressors and Coping Strategies During a MERS-CoV Outbreak. Clin. Med. Res. 2016, 14, 7-14. [CrossRef]

14. Baum, T.; Mooney, S.K.; Robinson, R.N.; Solnet, D. COVID-19's impact on the hospitality workforce-New crisis or amplification of the norm? Int. J. Contemp. Hosp. Manag. 2020, 32, 2813-2829. [CrossRef]

15. Pacheco, T.; Coulombe, S.; Khalil, C.; Meunier, S.; Doucerain, M.; Auger, É.; Cox, E. Job security and the promotion of workers' wellbeing in the midst of the COVID-19 pandemic: A study with Canadian workers one to two weeks after the initiation of social distancing measures. Int. J. Wellbeing 2020, 10, 58-76. [CrossRef]

16. Khan, K.I.; Niazi, A.; Nasir, A.; Hussain, M.; Khan, M.I. The Effect of COVID-19 on the Hospitality Industry: The Implication for Open Innovation. J. Open Innov. Technol. Mark. Complex. 2021, 7, 30. [CrossRef]

17. Zhang, S.X.; Wang, Y.; Rauch, A.; Wei, F. Unprecedented disruption of lives and work: Health, distress and life satisfaction of working adults in China one month into the COVID-19 outbreak. Psychiatr. Res. 2020, 288, 112958. [CrossRef]

18. Hamouche, S. COVID-19 and employees' mental health: Stressors, moderators and agenda for organizational actions. Emerald Open Res. 2020, 2, 15. [CrossRef]

19. Vo-Thanh, T.; Vu, T.-V.; Nguyen, N.P.; Van Nguyen, D.; Zaman, M.; Chi, H. How does hotel employees' satisfaction with the organization's COVID-19 responses affect job insecurity and job performance? J. Sustain. Tour. 2021, 29, 907-925. [CrossRef]

20. Brooks, S.K.; Dunn, R.; Amlôt, R.; Rubin, G.J.; Greenberg, N. A Systematic, Thematic Review of Social and Occupational Factors Associated With Psychological Outcomes in Healthcare Employees During an Infectious Disease Outbreak. J. Occup. Environ. Med. 2018, 60, 248-257. [CrossRef]

21. Stergiou, D.P.; Farmaki, A. Ability and willingness to work during COVID-19 pandemic:Perspectives of front-line hotel employees. Int. J. Hosp. Manag. 2021, 93, 102770. [CrossRef]

22. Hobfoll, S.E. Conservation of Resources Theory: Its Implication for Stress, Health, and Resilience. In The Oxford Handbook of Stress, Health, and Coping; Folkman, S., Ed.; Oxford University Press: Oxford, UK, 2011; pp. 127-147.

23. Bakker, A.; Demerouti, E. The Job Demands-Resources model: State of the art. J. Manag. Psychol. 2007, 22, 309-328. [CrossRef]

24. Demerouti, E.; Bakker, A. The Job Demands-Resources model: Challenges for future research. SA J. Ind. Psychol. 2011, 37, 1-9. [CrossRef] 
25. Rasdi, R.M.; Zaremohzzabieh, Z.; Ahrari, S. Financial Insecurity During the COVID-19 Pandemic: Spillover Effects on BurnoutDisengagement Relationships and Performance of Employees Who Moonlight. Front. Psychol. 2021, 12, 610138. [CrossRef] [PubMed]

26. Rathi, N.; Lee, K. Emotional exhaustion and work attitudes: Moderating effect of personality among frontline hospitality employees. J. Hum. Resour. Hosp. Tour. 2016, 15, 231-251. [CrossRef]

27. Bachem, R.; Tsur, N.; Levin, Y.; Abu-Raiya, H.; Maercker, A. Negative Affect, Fatalism, and Perceived Institutional Betrayal in Times of the Coronavirus Pandemic: A Cross-Cultural Investigation of Control Beliefs. Front. Psychiatr. 2020, 11, 589914. [CrossRef] [PubMed]

28. Serafini, G.; Parmigiani, B.; Amerio, A.; Aguglia, A.; Sher, L.; Amore, M. The psychological impact of COVID-19 on the mental health in the general population. Qjm Int. J. Med. 2020, 113, 531-537. [CrossRef]

29. Taylor, S. The Psychology of Pandemics: Preparing for the Next Global Outbreak of Infectious Disease; Cambridge Scholars Publishing: Newcastle upon Tyne, UK, 2019.

30. Kumar, A.; Somani, A. Dealing with Corona virus anxiety and OCD. Asian J. Psychiatr. 2020, 51, 102053. [CrossRef] [PubMed]

31. Liu, S.; Yang, L.; Zhang, C.; Xiang, Y.-T.; Liu, Z.; Hu, S.; Zhang, B. Online mental health services in China during the COVID-19 outbreak. Lancet Psychiatr. 2020, 7, e17-e18. [CrossRef]

32. Goodwin, R.; Hou, W.K.; Sun, S.; Ben-Ezra, M. Psychological and Behavioural Responses to COVID-19: A China-Britain Comparison. J. Epidemiol. Community Health 2021, 75, 189-192. [CrossRef] [PubMed]

33. Karakose, T.; Malkoc, N. Psychological impact of the COVID-19 pandemic on medical doctors in Turkey. Soc. Behav. Pers. Int. J. 2021, 49, 1-10. [CrossRef]

34. Mamun, M.A.; Sakib, N.; Gozal, D.; Bhuiyan, A.I.; Hossain, S.; Doza, B.; Al Mamun, F.; Hosen, I.; Safiq, M.B.; Abdullah, A.H.; et al. The COVID-19 pandemic and serious psychological consequences in Bangladesh: A population-based nationwide study. $J$. Affect. Disord. 2021, 279, 462-472. [CrossRef]

35. Mohammadi, S.M.; Ashtari, S.; Fetrat, M.K. The Psychological Impact of COVID-19 Pandemic on Mental Health of Iranian Population. Int. J. Travel Med. Glob. Health 2020, 9, 19-24. [CrossRef]

36. Serafim, A.P.; Durães, R.S.S.; Rocca, C.C.A.; Gonçalves, P.D.; Saffi, F.; Cappellozza, A.; Paulino, M.; Dumas-Diniz, R.; Brissos, S.; Brites, R.; et al. Exploratory study on the psychological impact of COVID-19 on the general Brazilian population. PLoS ONE 2021, 16, e0245868. [CrossRef] [PubMed]

37. Chaudhuri, S.; Sunil, R.; Bhatt, M.T.; Bhumika, T.V.; Thomas, N.; Puranik, A.; Shwethapriya, R. Weathering the Storm: Psychological Impact of COVID-19 Pandemic on Clinical and Nonclinical Healthcare Workers in India. Indian J. Crit. Care Med. 2021, 25, 16-20. [CrossRef]

38. American Psychiatric Association. Anxiety Disorders. In DSM-V. Diagnostic and Statistical Manual of Mental Disorders, 5th ed.; New School Library: New York, NY, USA, 2013. Available online: http:/ / repository.poltekkes-kaltim.ac.id/657/1/Diagnostic\%20 and \%20statistical\%20manual\%20of\%20mental\%20disorders\%20_\%20DSM-5\%20\%28\%20PDFDrive.com\%20\%29.pdf (accessed on 24 May 2021).

39. Kader Maideen, S.F.; Mohd Sidik, S.; Rampal, L.; Mukhtar, F. Prevalence, associated factors and predictors of anxiety: A community survey in Selangor, Malaysia. BMC Psychiatr. 2015, 15, 262. [CrossRef] [PubMed]

40. Yetgin, D.; Benligiray, S. The effect of economic anxiety and occupational burnout levels of tour guides on their occupational commitment. Asia Pac. J. Tour. Res. 2019, 24, 333-347. [CrossRef]

41. Kang, G.W.; Piao, Z.; Ko, J.Y. Descriptive or injunctive: How do restaurant customers react to the guidelines of COVID-19 prevention measures? The role of psychological reactance. Int. J. Hosp. Manag. 2021, 95, 102934. [CrossRef]

42. Turnipseed, D.L. Anxiety and Burnout in the Health Care Work Environment. Psychol. Rep. 1998, 82, 627-642. [CrossRef] [PubMed]

43. Marchand, G.; Russell, K.C.; Cross, R. An Empirical Examination of Outdoor Behavioral Healthcare Field Instructor Job-Related Stress and Retention. J. Exp. Educ. 2009, 31, 359-375. [CrossRef]

44. Yazıcı̆ğlu, I.; Kızanıklı, M.M. The Effects of Trait Anxiety on the Intention of Leaving and Burnout of Restaurant Employees. Tour. Acad. J. 2019, 5, 238-250.

45. Tarcan, G.Y.; Tarcan, M.; Top, M. An analysis of relationship between burnout and job satisfaction among emergency health professionals. Total Qual. Manag. Bus. Excel. 2016, 28, 1339-1356. [CrossRef]

46. Aumayr-Pintar, C.; Cerf, C.; Parent-Thirion, A. Burnout in the Workplace: A Review of Data and Policy Responses in the EU; Research report/Eurofound; Publications Office of the European Union: Luxembourg, Germany, 2018. [CrossRef]

47. Beck, T.J. A Phenomenological Analysis of Anxiety as Experienced in Social Situations. J. Phenomenol. Psychol. 2013, 44, 179-219. [CrossRef]

48. Chen, H.; Eyoun, K. Do mindfulness and perceived organizational support work? Fear of COVID-19 on restaurant frontline employees' job insecurity and emotional exhaustion. Int. J. Hosp. Manag. 2021, 94, 102850. [CrossRef]

49. Yakut, E.; Kuru, Ö.; Güngör, Y. Determination of the Influence of Work Overload and Perceived Social Support in the Effect of the Covid-19 Fears of Healthcare Personnel on Their Burnout by Structural Equation Modelling. EKEV Akad. Derg. 2020, 24, 241-262. [CrossRef]

50. Yildırım, M.; Solmaz, F. COVID-19 burnout, COVID-19 stress and resilience: Initial psychometric properties of COVID-19 Burnout Scale. Death Stud. 2020, 1-9. [CrossRef] 
51. Bakioğlu, F.; Korkmaz, O.; Ercan, H. Fear of COVID-19 and Positivity: Mediating Role of Intolerance of Uncertainty, Depression, Anxiety, and Stress. Int. J. Ment. Health Addict. 2020, 1-14. [CrossRef]

52. Satici, B.; Gocet-Tekin, E.; Deniz, M.E.; Satici, S.A. Adaptation of the Fear of COVID-19 Scale: Its Association with Psychological Distress and Life Satisfaction in Turkey. Int. J. Ment. Health Addict. 2020, 1-9. [CrossRef]

53. Greenhalgh, L.; Rosenblatt, Z. Job Insecurity: Toward Conceptual Clarity. Acad. Manag. Rev. 1984, 9, 438. [CrossRef]

54. Pienaar, J.; Witte, H.D.; Hellgren, J.; Sverke, M. The Cognitive/Affective Distinction of Job Insecurity: Validation and Differential Relations. S. Afr. Bus. Rev. 2013, 17, 1-22.

55. Sverke, M.; Hellgren, J.; Näswall, K. No security: A meta-analysis and review of job insecurity and its consequences. J. Occup. Health Psychol. 2002, 7, 242-264. [CrossRef] [PubMed]

56. Zoghbi-Manrique-De-Lara, P.; Ting-Ding, J.-M.; Guerra-Báez, R. Indispensable, Expendable, or Irrelevant? Effects of Job Insecurity on the Employee Reactions to Perceived Outsourcing in the Hotel Industry. Cornell Hosp. Q. 2016, 58, 69-80. [CrossRef]

57. Adebayo, D. The Moderating Effect of Self-efficacy on Job Insecurity and Organisational Commitment among Nigerian Public Servants. J. Psychol. Afr. 2006, 16, 35-43. [CrossRef]

58. Probst, T.; Jiang, L.; Graso, M. Leader-member exchange: Moderating the health and safety outcomes of job insecurity. J. Saf. Res. 2016, 56, 47-56. [CrossRef] [PubMed]

59. Mauno, S.; Cheng, T.; Lim, V. The Far-Reaching Consequences of Job Insecurity: A Review on Family-Related Outcomes. Marriage Fam. Rev. 2017, 53, 717-743. [CrossRef]

60. Di Stefano, G.; Venza, G.; Aiello, D. Associations of Job Insecurity with Perceived Work-Related Symptoms, Job Satisfaction, and Turnover Intentions: The Mediating Role of Leader-Member Exchange and the Moderating Role of Organizational Support. Front. Psychol. 2020, 11, 1329. [CrossRef] [PubMed]

61. Burgard, S.A.; Brand, J.E.; House, J.S. Perceived job insecurity and worker health in the United States. Soc. Sci. Med. 2009, 69, 777-785. [CrossRef] [PubMed]

62. Ciccarelli, A.; Fabrizi, E.; Romano, E.; Zoppoli, P. Health, Well-Being and Work History Patterns: Insight on Territorial Differences. Soc. Indic. Res. 2020, 1-19. [CrossRef]

63. Virtanen, M.; Nyberg, S.T.; Batty, G.; Jokela, M.; Heikkila, K.; Fransson, E.; Alfredsson, L.; Bjorner, J.B.; Borritz, M.; Burr, H.; et al. Perceived job insecurity as a risk factor for incident coronary heart disease: Systematic review and meta-analysis. BMJ 2013, 347, f4746. [CrossRef]

64. Ferrie, J.E.; Shipley, M.J.; Stansfeld, S.A.; Marmot, M. Effects of chronic job insecurity and change in job security on self reported health, minor psychiatric morbidity, physiological measures, and health related behaviours in British civil servants: The Whitehall II study. J. Epidemiol. Community Health 2002, 56, 450-454. [CrossRef]

65. Shin, Y.; Hur, W.-M. When do job-insecure employees keep performing well? The buffering roles of help and prosocial motivation in the relationship between job insecurity, work engagement, and job performance. J. Bus. Psychol. 2021, 36, 659-678. [CrossRef]

66. Jiang, L.; Probst, T.M. The rich get richer and the poor get poorer: Country- and state-level income inequality moderates the job insecurity-burnout relationship. J. Appl. Psychol. 2017, 102, 672-681. [CrossRef]

67. Probst, T.M. The Impact of Job Insecurity on Employee Work Attitudes, Job Adaptation and Organizational Withdrawal Behaviours. In The Psychology of Work: Theoretically Based Empirical Research; Brett, J.M., Drasgow, F., Eds.; Lawrence Erlbaum: Mahwah, NJ, USA, 2002; pp. 141-168.

68. Rothmann, S.; Jackson, L.T.B.; Kruger, M.M. Burnout and job stress in a local government: The moderating effect of sense of coherence. SA J. Ind. Psychol. 2003, 29, 52-60. [CrossRef]

69. Çetin, Y.D.D.C. The Relationship between Job Insecur1-Ity and Burnout-Sample of Municipal Polices. Celal Bayar Univ. J. Soc. Sci. 2015, 13, 73-95. [CrossRef]

70. Bitmiş, M.G.; Ergeneli, A. How Psychological Capital Influences Burnout: The Mediating Role of Job Insecurity. Procedia Soc. Behav. Sci. 2015, 207, 363-368. [CrossRef]

71. Oprea, B.; Iliescu, D. Burnout and Job Insecurity: The Mediating Role of Job Crafting. Psihol. Resur. Umane 2015, 13, $232-244$.

72. Douglas, J.; Haar, J.; Harris, C. Job Insecurity and Job Burnout: Does Union Membership Buffer the Detrimental Effects? N. Z. J. Hum. Resour. Manag. 2017, 17, 23-40.

73. Katlav, E.Ö.; Çetin, B.; Perçin, N.Ş. The Effect of Tourist Guides' Perceptions of Job Insecurity on Burnout. J. Travel Hosp. Manag. 2020, 18, 37-55. [CrossRef]

74. McCarthy, C.P. The Under 40 Financial Planning Guide: From Graduation to Your First House; Silver Lake Publishing: Aberdeen, WA, USA, 1996.

75. Joo, S. Personal Financial Wellness. In Handbook of Consumer Finance Research; Xiao, J.J., Ed.; Springer: New York, NY, USA, 2008.

76. Halleröd, B.; Seldén, D. The Multi-dimensional Characteristics of Wellbeing: How Different Aspects of Wellbeing Interact and Do Not Interact with Each Other. Soc. Indic. Res. 2013, 113, 807-825. [CrossRef]

77. Brüggen, E.C.; Hogreve, J.; Holmlund, M.; Kabadayi, S.; Löfgren, M. Financial well-being: A conceptualization and research agenda. J. Bus. Res. 2017, 79, 228-237. [CrossRef]

78. Panisch, L.S.; Prost, S.G.; Smith, T.E. Financial well-being and physical health related quality of life among persons incarcerated in jail. J. Crime Justice 2019, 42, 444-461. [CrossRef]

79. CFPB (Consumer Financial Protection Bureau). Financial Well-Being: The Goal of Financial Education. 2015. Available online: https:/ / files.consumerfinance.gov/f/201501_cfpb_report_financial-well-being.pdf (accessed on 19 May 2021). 
80. Prendergast, S.; Blackmore, D.; Kempson, E.; Kutin, J. Financial Well-Being: A Survey of Adults in Australia. ANZ Banking Group Limited. 2018. Available online: https:/ / www.financialcapability.gov.au/files/anz-financial-wellbeing-summary-reportaustralia.pdf (accessed on 21 May 2021).

81. Swift, S.L.; Bailey, Z.; Al Hazzouri, A.Z. Improving the Epidemiological Understanding of the Dynamic Relationship Between Life Course Financial Well-Being and Health. Curr. Epidemiol. Rep. 2019, 6, 28-33. [CrossRef]

82. Link, B.G.; Phelan, J. Social Conditions as Fundamental Causes of Disease. J. Health Soc. Behav. 1995, 35, 80. [CrossRef]

83. Prenovitz, S. What happens when you wait? Effects of Social Security Disability Insurance wait time on health and financial well-being. Health Econ. 2021, 30, 491-504. [CrossRef]

84. Arber, S.; Fenn, K.; Meadows, R. Subjective financial well-being, income and health inequalities in mid and later life in Britain. Soc. Sci. Med. 2014, 100, 12-20. [CrossRef] [PubMed]

85. Kim, J.; Garman, E.; Sorhaindo, B. Relationships Among Credit Counseling Clients' Financial Well-Being, Financial Behaviors, Financial Stressor Events, and Health. Financ. Couns. Plan. 2003, 14, 75-87.

86. O'Neill, B.; Sorhaindo, B.; Xiao, J.J.; Garman, E.T. Negative Health Effects of Financial Stress. Consum. Interes. Annu. 2005, 51, $260-262$.

87. O'Neill, B.; Xiao, J.J.; Sorhaindo, B.; Garman, E. Financially Distressed Consumers: Their Financial Practices, Financial Well-Being, and Health. Hum. Dev. Fam. Sci. Fac. Publ. 2005, 16, 73-87.

88. Campara, J.P.; Vieira, K.M.; Potrich, A.C.G. Satisfação Global de Vida e Bemestar Financeiro: Desvendando a percepção de beneficiários do Programa Bolsa Família. Braz. J. Public Adm. 2017, 51, 182-200. [CrossRef]

89. Maslach, C.; Schaufeli, W.B.; Leiter, M.P. Job Burnout. Annu. Rev. Psychol. 2001, 52, 397-422. [CrossRef]

90. Verduzco-Gutierrez, M.; Larson, A.R.; Capizzi, A.N.; Bean, A.C.; Do, R.D.Z.; Odonkor, C.A.; Bosques, G.; Silver, J.K. How Physician Compensation and Education Debt Affects Financial Stress and Burnout: A Survey Study of Women in Physical Medicine and Rehabilitation. PMER 2021, 13, 836-844. [CrossRef]

91. Dündar, G.İ.; Akduman, G.; Hatïpoğlu, Z. The Relationship of Financial Wellbeing to Burnout According to Generations. Istanb. Manag. J. 2018, 29, 31-50.

92. Sabri, M.F.; Aw, E.C.-X. Untangling financial stress and workplace productivity: A serial mediation model. J. Work. Behav. Health 2020, 35, 211-231. [CrossRef]

93. Republic of Turkey Ministry of Culture and Tourism. Tourism Statistics (January-September 2020). Available online: https: / /yigm.ktb.gov.tr/Eklenti/81888,30032020yilliksinirbulteni-xlsx-1xlsx.xlsx?0. (accessed on 10 August 2021).

94. Soper, D.S. A-Priori Sample Size Calculator for Structural Equation Models [Software]. 2021. Available online: https://www. danielsoper.com/statcalc/calculator.aspx?id=89 (accessed on 1 June 2021).

95. Lee, S.A. Coronavirus Anxiety Scale: A brief mental health screener for COVID-19 related anxiety. Death Stud. 2020, 44, 393-401. [CrossRef] [PubMed]

96. Evren, C.; Evren, B.; Dalbudak, E.; Topcu, M.; Kutlu, N. Measuring anxiety related to COVID-19: A Turkish validation study of the Coronavirus Anxiety Scale. Death Stud. 2020, 1-7. [CrossRef] [PubMed]

97. Castro-González, S.; Fernández-López, S.; Rey-Ares, L.; Rodeiro-Pazos, D. The Influence of Attitude to Money on Individuals' Financial Well-Being. Soc. Indic. Res. 2020, 148, 747-764. [CrossRef]

98. Malach-Pines, A. The Burnout Measure, Short Version. Int. J. Stress Manag. 2005, 12, 78-88. [CrossRef]

99. Anderson, J.C.; Gerbing, D.W. Structural equation modeling in practice: A review and recommended two-step approach. Psychol. Bull. 1988, 103, 411-423. [CrossRef]

100. Schermelleh-Engel, K.; Moosbrugger, H.; Müller, H. Evaluating the Fit of Structural Equation Models: Tests of Significance and Descriptive Goodness-of-Fit Measures. Methods Psychol. Res. 2003, 8, $23-74$.

101. Bagozzi, R.P.; Yi, Y. On the evaluation of structural equation models. J. Acad. Mark. Sci. 1988, 16, 74-94. [CrossRef]

102. Gravetter, F.; Wallnau, L. Essentials of Statistics for the Behavioral Sciences, 8th ed.; Wadsworth: Belmont, CA, USA, 2014.

103. Hair, J.F.; Black, W.C.; Babin, B.J.; Anderson, R.E. Multivariate Data Analysis; Prentice-Hall: Upper Saddle River, NJ, USA, 2010.

104. Kline, R.B. Principles and Practice of Structural Equation Modeling, 4th ed.; Guilford Press: New York, NY, USA, 2016.

105. Nunnally, J.C.; Bernstein, I.H. Psychometric Theory, 3rd ed.; McGraw-Hill: New York, NY, USA, 1994.

106. Fornell, C.; Larcker, D.F. Evaluating Structural Equation Models with Unobservable Variables and Measurement Error. J. Mark. Res. 1981, 18, 39-50. [CrossRef]

107. Podsakoff, P.M.; MacKenzie, S.B.; Podsakoff, N.P. Sources of Method Bias in Social Science Research and Recommendations on How to Control It. Annu. Rev. Psychol. 2012, 63, 539-569. [CrossRef]

108. Fuller, C.; Simmering, M.J.; Atinc, G.; Atinc, Y.; Babin, B.J. Common methods variance detection in business research. J. Bus. Res. 2016, 69, 3192-3198. [CrossRef]

109. Podsakoff, P.M.; MacKenzie, S.B.; Lee, J.Y.; Podsakoff, N.P. Common method biases in behavioral research: A critical review of the literature and recommended remedies. J. Appl. Psychol. 2003, 88, 879-903. [CrossRef]

110. Chang, S.-J.; Van Witteloostuijn, A.; Eden, L. From the Editors: Common method variance in international business research. J. Int. Bus. Stud. 2010, 41, 178-184. [CrossRef]

111. Yan, J.; Kim, S.; Zhang, S.X.; Foo, M.-D.; Alvarez-Risco, A.; Del-Aguila-Arcentales, S.; Yáñez, J.A. Hospitality workers' COVID-19 risk perception and depression: A contingent model based on transactional theory of stress model. Int. J. Hosp. Manag. 2021, 95, 102935. [CrossRef] 
112. Darvishmotevali, M.; Ali, F. Job insecurity, subjective well-being and job performance: The moderating role of psychological capital. Int. J. Hosp. Manag. 2020, 87, 102462. [CrossRef]

113. Buss, P.M. Public health and the world economic crisis. J. Epidemiol. Community Health 2009, 63, 417. [CrossRef] [PubMed]

114. Chang, S.-S.; Gunnell, D.; Sterne, J.A.; Lu, T.-H.; Cheng, A.T. Was the economic crisis 1997-1998 responsible for rising suicide rates in East/Southeast Asia? A time-trend analysis for Japan, Hong Kong, South Korea, Taiwan, Singapore and Thailand. Soc. Sci. Med. 2009, 68, 1322-1331. [CrossRef]

115. Roca, M.; Gili, M.; Garcia-Campayo, J.; García-Toro, M. Economic crisis and mental health in Spain. Lancet 2013, 382, 1977-1978. [CrossRef]

116. Lam, C.C.-C.; Cheung, F.; Wu, A.M. Job Insecurity, Occupational Future Time Perspective, and Psychological Distress Among Casino Employees. J. Gambl. Stud. 2019, 35, 1177-1191. [CrossRef]

117. Diener, E.; Biswas-Diener, R. Will Money Increase Subjective Well-Being? Soc. Indic. Res. 2002, 57, 119-169. [CrossRef]

118. Mucci, N.; Giorgi, G.; Roncaioli, M.; Perez, J.F.; Arcangeli, G. The correlation between stress and economic crisis: A systematic review. Neuropsychiatr. Dis. Treat. 2016, 12, 983-993. [CrossRef] [PubMed]

119. Houdmont, J.; Kerr, R.; Addley, K. Psychosocial factors and economic recession: The Stormont Study. Occup. Med. 2012, 62, 98-104. [CrossRef] [PubMed]

120. Giorgi, G.; Shoss, M.; Leon-Perez, J.M. Going beyond workplace stressors: Economic crisis and perceived employability in relation to psychological distress and job dissatisfaction. Int. J. Stress Manag. 2015, 22, 137-158. [CrossRef]

121. Dimoff, J.K.; Kelloway, E.K. Mental Health Problems are Management Problems: Exploring the Critical Role of Managers in Supporting Employee Mental Health. Organ. Dyn. 2018, 48, 105-112. [CrossRef]

122. Karatepe, O.M.; Yavas, U.; Babakus, E.; Deitz, G.D. The effects of organizational and personal resources on stress, engagement, and job outcomes. Int. J. Hosp. Manag. 2018, 74, 147-161. [CrossRef]

123. Choi, H.-M.; Mohammad, A.A.; Kim, W.G. Understanding hotel frontline employees' emotional intelligence, emotional labor, job stress, coping strategies and burnout. Int. J. Hosp. Manag. 2019, 82, 199-208. [CrossRef]

124. Koo, B.; Yu, J.; Chua, B.-L.; Lee, S.; Han, H. Relationships among Emotional and Material Rewards, Job Satisfaction, Burnout, Affective Commitment, Job Performance, and Turnover Intention in the Hotel Industry. J. Qual. Assur. Hosp. Tour. 2020, 21, 371-401. [CrossRef]

125. Hobfoll, S.E. The Influence of Culture, Community, and the Nested-Self in the Stress Process: Advancing Conservation of Resources Theory. Appl. Psychol. 2001, 50, 337-421. [CrossRef]

126. Shoss, M.K.; Probst, T.M. Multilevel Outcomes of Economic Stress: An Agenda for Future Research. In The Role of the Economic Crisis on Occupational Stress and Well Being; Perrewé, P.L., Halbesleben, J.R.B., Rosen, C.C., Eds.; Research in Occupational Stress and Well Being; Emerald Group Publishing Limited: Bradford, UK, 2012; Volume 10, pp. 43-86. [CrossRef]

127. Hobfoll, S.E. Conservation of resources: A new attempt at conceptualizing stress. Am. Psychol. 1989, 44, 513-524. [CrossRef]

128. Hobfoll, S.E.; Halbesleben, J.; Neveu, J.-P.; Westman, M. Conservation of Resources in the Organizational Context: The Reality of Resources and Their Consequences. Annu. Rev. Organ. Psychol. Organ. Behav. 2018, 5, 103-128. [CrossRef]

129. Bakker, A.; Demerouti, E.; Schaufeli, W. Dual processes at work in a call centre: An application of the job demands-Resources model. Eur. J. Work. Organ. Psychol. 2003, 12, 393-417. [CrossRef]

130. Xanthopoulou, D.; Bakker, A.B.; Demerouti, E.; Schaufeli, W.B. The role of personal resources in the job demands-resources model. Int. J. Stress Manag. 2007, 14, 121. [CrossRef]

131. Bohle, P.; Quinlan, M. Managing Occupational Health and Safety: A Multidisciplinary Approach, 2nd ed.; Macmillan: Melbourne, Australia, 2000.

132. Üngüren, E.; Koç, T.S. Konaklama İşletmelerinde İş Sağlı̆̆1 ve Güvenliği Uygulamalarının Örgütsel Güven Üzerindeki Etkisi. ISGUC J. Ind. Relat. Hum. Resour. 2016, 18, 123-156. [CrossRef]

133. Ahorsu, D.K.; Lin, C.-Y.; Imani, V.; Saffari, M.; Griffiths, M.D.; Pakpour, A.H. The Fear of COVID-19 Scale: Development and Initial Validation. Int. J. Ment. Health Addict. 2020, 1-9. [CrossRef] [PubMed]

134. Bareket-Bojmel, L.; Shahar, G.; Margalit, M. COVID-19-Related Economic Anxiety Is As High as Health Anxiety: Findings from the USA, the UK, and Israel. Int. J. Cogn. Ther. 2020, 1-9. [CrossRef]

135. Labrague, L.J.; de Los Santos, J.A.A. Fear of COVID-19, psychological distress, work satisfaction and turnover intention among frontline nurses. J. Nurs. Manag. 2021, 29, 395-403. [CrossRef]

136. Schaufeli, W.; Bakker, A. Job demands, job resources, and their relationship with burnout and engagement: A multi-sample study. J. Organ. Behav. 2004, 25, 293-315. [CrossRef]

137. Watterson, A. COVID-19 in the UK and Occupational Health and Safety: Predictable not Inevitable Failures by Government, and Trade Union and Nongovernmental Organization Responses. EW Solut. J. Environ. Occup. Health Policy 2020, $30,86-94$. [CrossRef] [PubMed] 